\title{
Analysis of Trade Condition in Ras Region
}

\section{Slavica Andelićín, Amer Rastićc ${ }^{35}$, Dejan llić36}

\begin{abstract}
Modern academic literature in the field of trade in macro and mesoeconomic atmosphere, istrying to shed light on the data which defines exchange flows in intra and international environment. The study of this work is based on the database based through state registers, where with their sizing and analysis, we are coming to a deeper insight into the condition of market channels ofRas region and its relationship with the environment. The aim of this work is meticulous interpretation of trade patterns as a result of macro and meso trade policy, which could serve as an incentive for local and governmental structures in developing commercial potential of the southern part of our country
\end{abstract}

KEY WORDS: Trade, Analyze, Trade Policy, Food Basket, Purchasing Power, Living Standards

JEL: 024, 044

UDC: $339.13 .017(497.11)$

330.59

COBISS.SR-ID 238316812

\footnotetext{
${ }^{34}$ High Business School "prof. RadomirBojković "Krusevac, Serbia,e-mail: slavica.andjelic@indmanager.edu.rs

${ }^{35}$ High Business School "prof. RadomirBojković "Krusevac, Serbia

${ }^{36}$ Faculty for Strategic and Operational Management, Belgrade, Serbia
} 


\section{INTRODUCTION}

The term "free trade" is believed to have originated at the end of the sixteenth century in the parliamentary debates over foreign trade monopolies (ChristopherE.S. Warburton, 2010, p. 67). The traditional argument that participation in international trade theory results in a better allocation of resources and an improved specialization remains valid. Therefore developing countries should take advantage of the opportunities offered by international trade.(L. Berlage, 1998, p.374)

In addition to the strong design of the entire macro policy, there are needs for sufficient panel of trade policy that certainly achieve positive repercussions on the economic development and its performance. (Krueger, 1997). In addition to a certain skepticism of academics, the improvement of trade point of the country in terms of its openness to trade and its commercial legacy privileges in external trade, significantly defines the trend of prosperity in the country. (Rodriguez, 2000; Harrison, 1996). Context of research, when we look at the trade integration on European soil, also have positive implications that were recorded, with good trade policy and openness to external trade. (Dritsakis, 2016). If we consider all these argumentation, analysis of trade in our country is becoming a priority.In 2016, Serbian economy still feel the consequences of global economic crisis, which effects are partially alleviated with mechanism of economic policy( Anđelić, 2015)

Thetendency fordesigning policy measures of the Republic of Serbia construct the positive climate in trade, both at regionalan dinternational level. Gudelines for trade development in Ras region are defined by result sofanaly zing population spurchasing power, number of employees in Group XI interests - commerce, catering and tourism (dealers, catering and tourism professions), paid salaries in Ras region, foreign trade exchange and processes of exchanging goods and services. In constant contact with all economic entities engaged in wholesale trade and retail trade, define the current status, conditions of business operations and possible solutions for problems that occur when performing the activities.

\section{FLUCTUATIONS OF PURCHASING POWER IN RAS DISTRICT}

The purchasing power of population is defined as the ratio of average salary in Ras zone and the consumer basket of the Republic of Serbia. Miminimal purchasing power defines projection on minimal consumer basket of the Republic of Serbia.

Table 1. Averagesalary in Ras region

\begin{tabular}{|c|c|c|c|c|c|c|c|c|}
\hline \multirow{4}{*}{$\begin{array}{l}\text { Town/ } \\
\text { District }\end{array}$} & \multicolumn{4}{|c|}{ Average salary summary } & \multicolumn{4}{|c|}{$\begin{array}{c}\text { Average salarywithout taxes and contributions } \\
\text { summary }\end{array}$} \\
\hline & \multicolumn{2}{|c|}{ RSD } & \multicolumn{2}{|c|}{$\begin{array}{l}\text { Nominal } \\
\text { index }\end{array}$} & \multicolumn{2}{|c|}{ RSD } & \multicolumn{2}{|c|}{$\begin{array}{l}\text { Nominal } \\
\text { index }\end{array}$} \\
\hline & VI & $\mathrm{I}-\mathrm{VI}$ & $\mathrm{VI} / \mathrm{V}$ & $2014 /$ & VI & I-VI & $\mathrm{VI} / \mathrm{V}$ & $2014 /$ \\
\hline & 2014 & 2014 & 2014 & 2013 & 2014 & 2014 & 2014 & 2013 \\
\hline Aleksandrovac & 43.310 & 42.018 & 90,5 & 93,4 & 31.216 & 30.333 & 90,4 & 93,9 \\
\hline Brus & 44.275 & 43.331 & 106,6 & 97,6 & 32.174 & 31.407 & 106,7 & 98,2 \\
\hline Varvarin & 50.093 & 48.868 & 103,1 & 104,6 & 36.294 & 35.380 & 103,5 & 104,7 \\
\hline Kruševac & 52.738 & 49.166 & 111,1 & 99,4 & 38.728 & 36.053 & 112,3 & 98,8 \\
\hline Trstenik & 46.373 & 42.868 & 109,3 & 96,3 & 36.301 & 32.926 & 112,4 & 96,1 \\
\hline Ćićevac & 39.508 & 37.122 & 111,2 & 98,5 & 30.268 & 28.427 & 114,4 & 97,3 \\
\hline Rasinskiokrug & 49.529 & 46.469 & 108,1 & 98,2 & 36.765 & 34.331 & 109,5 & 97,7 \\
\hline SRBIJA & 61.992 & 59.888 & 101,7 & 101,0 & 44.883 & 43.415 & 101,6 & 101,4 \\
\hline
\end{tabular}


The average salary in the Ras district, paid in June 2014 according to data of the National Employment affiliate in Krusevac amounts 49.529 dinars. The average wage without taxes and contributions in Ras zone, paid in June 2014 according to data of the National Employment affiliate in Krusevac amounts to 36.785 dinars. Structure of average earnings described in Tables, apart from being indispensable category for the analysis of purchasing power in defined area, it actually also provides a view insight into compact concentration of income in indicated district. In absolute view, the amount of the average salaries in Ras region recorded a positive trend in 2014 (see Table 2), while the relative context of the average wages in the cities of Ras region, as leaders, the ones that lead in amount of paid average wages are Kruševac (52.738 VI 2014) and Varvarin (50. 093 VI 2014), which is $10 \%-15 \%$ more than the average salary received in Aleksandrovac (VI 43. 310 2014) and Brus (VI 44. 275 2014).

Table 2: Consumer basket in Ras region

\begin{tabular}{||c|c|c|c|c|c||}
\hline Year-Mesec & $\begin{array}{c}\text { Average salarywithout } \\
\text { taxes and contributions }\end{array}$ & \multicolumn{2}{|c|}{ Consumer basket inSerbia } & \multicolumn{2}{c|}{$\begin{array}{c}\text { Consumer basket and } \\
\text { salary ratio }\end{array}$} \\
\hline & & Average & Minimal & $(3: 2)$ & $(4: 2)$ \\
\hline 1 & 2 & 3 & 4 & 5 & 6 \\
\hline Januar 2014. & 37.966 & $55.717,94$ & $34.177,96$ & 1,73 & 0,90 \\
\hline Februar 2014. & 44.057 & $55.718,72$ & $34.090,00$ & 1,49 & 0,77 \\
\hline Mart 2014. & 43.452 & $55.463,27$ & $33.974,95$ & 1,51 & 0,78 \\
\hline April 2014. & 45.847 & $55.766,40$ & $34.181,31$ & 1,43 & 0,75 \\
\hline Maj 2014. & 44.184 & $55.922,53$ & $34.330,96$ & 1,49 & 0,78 \\
\hline Jun 2014. & 44.883 & $55.948,43$ & $34.280,37$ & 1,47 & 0,76 \\
\hline
\end{tabular}

Source: Agency for Regional Development, Ras region, Krusevac

The purchasing power of population, according to available data, as ratio of average salary in Ras region paid in June 2014 and average consumer basket in Serbia for June 2014, is 1,33 average wages. Purchasing power of population in Ras region of Minimal consumer basket amounts 0,69 average salaries.

Purchasing power of population according to available data, as ratio ofaverage salary without taxes and contributions in Ras region paid in June 2014, and Average consumer basket in Serbia for June 2014, amounts 1,82 average salaries. The purchasing power in Ras region of Minimal consumer bascet is 0.93 average salaries.

Consumer prices for goods and services in June 2014, compared to May 2014 (monthly index) are higher on average by $0,1 \%$. The annual increase in consumer prices was $1,3 \%$ (June 2014 , comparedto June 2013), while in relation to December 2013 increased by $2 \%$ (current increase).

Observed with main groups of products and services divided by purpose of consumption in June 2014, compared to thelast year, the largest increase of prices was recorded in the groups: Recreation and culture $(4,2 \%)$, Clothing and footwear $(0,3 \%)$, Communications $(0,2 \%)$ amd Transport $(0,1 \%)$. The decrease of prices was recorded in group: Furniture, household equipment ad routine household maintenance $(-0,1 \%)$, education $(-0,2 \%)$ and in the groups food and non-alcoholic drinks and tobacco, and Health (by -0,1\%).

The summary of employees in the occupational group: trade, catering and tourism (dealers, catering and tourism professionals) according to the National Employment Service affiliation in Krusevac is 2.546 .

The total number of employees in wholesale and retail trade in Ras region in March 2014, is 2.648. The largest number of employees in these industries was recorded in Municipality Krusevac with 1.929 employees, the lowest number of employees was recorded in Municipality Brus with 41 employees. In relation to the total number of employees in wholesale and retail in 2013, which amounted 2.830, employees in first quarter of 2014 decreased for 182. 
Domicile legislation treats the theme of external trade goods and services, in a way that foreign trade represents circulation between domestic and foreign entities that is performed on the basis of an agreement concluded in accordance with national and international agreements. (Law of Foreign Trade, "Sl. glasnik RS", br. 36/2009, 36/2011 - dr. zakon, 88/2011 i 89/2015 - dr. zakon)

According to available data from Regional Economic Board Krusevac, total external trade for Rasregionin the first half of 2014. Amounts 177, 55 million dollars. The value of exported good for period January-June 2014 amounts 99,55 million dollars, compared to the same period in last year, increased by $10,8 \%$. Total imports amounts to 78 million dollars, compared to the same period of 2013, it decreased by 16,9\%. In Ras region, in the first half of 2014 was recorded surplus of 21.5 million dollars. The coverage of import by exportin this period amountsto127,5\%, while this indicator, measured in whole Serbia level amounts 73,5\%. Export of Ras region in total export of the Republic of Serbia participates with $0,7 \%$.

Major foreign external trade partners in the period January-June 2014 in export of Ras region are:

Table 3: Export defined in millions USD

\begin{tabular}{||l|l|l|l||}
\hline \hline Ordinal number & Countries & January - June 2014. & Increase/Decreasecompared to 2013. \% \\
\hline 1. & Great Britany & 18,648 & Increased by $44,5 \%$ \\
\hline 2. & Germany & 13,87 & Increased by $71,6 \%$ \\
\hline 3. & Russian Federation & 12,435 & Decreased by $13,2 \%$ \\
\hline 4. & Bosnia and Herzegovina & 7,931 & Increased by $6,5 \%$ \\
\hline 5. & Montenegro & 6,515 & Increased by $25,3 \%$ \\
\hline
\end{tabular}

Source: Agency for Regional Development,Ras region, Krusevac

Main external trade partners for import in Ras region are:

Table 4: Import defined in millions USD

\begin{tabular}{||l|l|l|l||}
\hline \hline Ordinal number & Countries & January-June 2014. & $\begin{array}{c}\text { Increase/Decrease } \\
\text { compared to 2013.\% }\end{array}$ \\
\hline 1. & Germany & 6,889 & Decreased breasedbyy $16,2 \%$ \\
\hline 2. & Italy & 5,557 & Decreased by 33,5\% \\
\hline 3. & Turkey & 5,410 & Increased by $15,7 \%$ \\
\hline 4. & China & 5,007 & Decreased by $39,5 \%$ \\
\hline 5. & Romania & 4,714 & Decreased by $16,4 \%$ \\
\hline
\end{tabular}

Source: Agency for Regional Development,Ras region, Krusevac

According to the types of goods, the export of Ras zone for period January-June 2014, the largest participation has the following goods: external pneumatic tires, non-alcoholic drinks, raspberries, new external pneumatic tires, with tractor pattern, hydraulic systems with linear movement, edible plants fruits, berries, wine, blackberries and others.

According to the types of goods in import of Ras region for the same period, the largest participation has the following goods: natural rubber, oils difficult for design or thread pneumatic tires, paper fluting, test liner, twisted wire, brown coal and lignite, pneumatic tires for new passenger cars, ropes, cables with cross-section over $3 \mathrm{~mm}$, cord fabric.

Ras region has a significant external trade with neighboring countries. If we look at trade with neighboring countries, Ras region for the first half of 2014, has the largest export to Bosnia and Herzegovina, Montenegro, Macedonia, but the largest import was from Romania, Croatia and Macedonia.Companies that took the largest share in external trade are: Cooper Tire \& Rubber Company Serbia d.o.o. Kruševac, AD Vino ŽupaAleksandrovac. Trajal Hem AD Kruševac. 
The most important exporters of Ras region, for period January-June 2014 were: Cooper Tire \& Rubber Company Serbia d.o.o. Kruševac, AD Vino Župa Aleksandrovac. Trajal Hem AD Kruševac, Župafrigo Aleksandrovac, Servoupravljači u restrukturiranjuTrstenik,.

When we talk about export orientation in Ras region, defined by economic zones, it show that the largest share of export in Ras region oriented to the countries of European Union and CEFTA region, and oriented to the market of Russian Federation too.

In the external trade of region, for period January-June 2014, the largest participation have companies from Krusevac, which participate in the export of district with 54,4\%, and in import with $77,1 \%$, followed by companies from Aleksandrovac, they participate in export with 18,3\% and in import with 7,2\%, companies from Trstenik, which have allotment in in export with 15 , $5 \%$, while in import they participate with $12 \%$.

\section{FRANCHISE AS A CATALYST FOR DEVELOPMENT OF TRADE}

Franchise business module includes two interested parties, franchisor and franchisee. It include the transfers of brand, business format, technology, well-established supply channels and sales. In principle, everything is defined through a franchise agreement. Administrator can achieve different types of compensation, the most common is to share in the net profits franchisee.

The system integrates all the necessary mechanism for the operation and as such gives a positive impetus to entrepreneurship, and entrepreneurship is a fundamental prerequisite for successive trend of modern economy. (Michael, 2014, p. 612-620). In Serbia, the model of franchising arrived relatively early, mid-70s (Coca-Cola, Avis, Diners Club International, Intercontinental, Hyatt, American Express, McDonald's), and in 2007 founded the Serbian Chamber of Commerce Center for franchising. Studies show that Serbia is lagging behind in this system operating. (Stefanovic, 2013, p. 115-127). The inclusion of this mechanism in the sector of trade through governmental structures and institutions of the Republic of Serbia, and consequently in the Rasina region, would contribute to long-term economic viability and vitality.

\section{CONCLUSION}

Active economic and political mechanis of national appliance is necessary to intensify cooperation with major foreign trade partners, operating with achieved foreign trade agreement of the Republic of Serbia, favoring their strengths and contracting new. Import of Ras region mainly recorded a decrease, while export is highly positive in 2013 compared to the previous year. If we look at trade with neighboring countries, export is primarily realized to Bosnia and Herzegovina, Montenegro and Macedonia, and import to Romania, Croatia and Macedonia.

Effective implementation of strategy that define development of trade in Rasregion has to provide an active trade policy development at different levels. On macro level should be provided policy that intensify the market development and trade. Along with this, at the enterprise level should be fully developed a modern marketing concept and the whole modern trade management. 


\section{REFERENCES}

[1] Agencija za regionalni razvoj Rasinskog okruga, (2015). Statistika privrednih kretanja u regionu, Kruševac

[2] Anđelić, S., Čukanović Karavidić, M., Karavidić, S., (2015). Organization supportand institution alenvironment for enterepreneurship development, International Review, Faculty of Business Economics and Entrepreneurship, Belgrade, No. 3-4/2015, pp. 8-14.

[3] Berlage, L., (1998). Trade Strategy and Economic Growth in Developing Countries, Tijdschriftvoor Economie en Management Vol. XLIII, 3, 1998

[4] Christopher E.S. Warburton, (2010). International trade law and trade theory, Journal Article Journal of International Trade Law and Policy, pp.67

[5] Dritsakis, N., Stamatiou, P., (2016). Trade Openness and Economic Growth: A Panel Cointegration and Causality Analysis for the Newest EU Countries. Romanian Economic Journal, 18(59), pp.45-60.

[6] Harrison, A., (1996). Openness and growth: A time-series, cross-country analysis for developing countries. Journal of development Economics, 48(2), pp.419-447.

[7] Krueger, A.O., (1997). Trade policy and economic development: how we learn (No. w5896). National Bureau of Economic Research.

[8] Michael, S.C., (2014). Can franchising be an economic development strategy? An empirical investigation. Small business economics, 42(3), pp.611-620.

[9] Regionalna privredna komora Kruševac, (2015). Pregled kretanja trgovine u Rasinskom okrugu, Kruševac

[10] Rodriguez, F. Rodrik, D., (2000). Trade policy and economic growth: a skeptic's guide to the cross-national evidence. NBER macroeconomics annual, 15, pp.261-325.

[11] Stefanović, S., Stanković, M., (2013). Comparative analysis of the development of franchising in Serbia and worldwide. Marketing, 44(2), pp.115-127.

[12]Zakon o spoljnotrgovinskom poslovanju, "Sl. glasnik RS", br. 36/2009, 36/2011 - dr. zakon, 88/2011 i 89/2015 - dr. zakon)

\section{Article history:}

- Received 15 August 2016

- First revision 30 November 2016

- Second revision 15 February 2017

- Accepted 15 May 2017 